\title{
The Characteristics of Adopters and Non-Adopters of Digital Marketing Application among Micro, Small and Medium Enterprises (MSMES)
}

\author{
Abdul Khaliq Abdul Hamid ${ }^{1}$, Nor Khasimah Aliman²* \\ ${ }^{1}$ Universiti Terbuka Malaysia \\ Ipoh, Malaysia \\ ${ }^{2}$ Associate Professor, Universiti Teknologi MARA \\ Perak Branch, Seri Iskandar, Malaysia \\ *Corresponding author's email:nka980@uitm.edu.my
}

\begin{abstract}
This article aims to reveals the profiles of adopters and non-adopters of digital marketing application among Micro, Small and Medium Enterprises (MSMEs) in Malaysia. This research focuses primarily on MSMEs in Perak State. The researchers employed a quantitative approach to meet the research objectives. A survey involving 400 MSMEs in Perak State was conducted to investigate the adopters and non-adopters of digital marketing application. The 361 completed survey data were analyzed using descriptive statistical tools. The results found that out of 361 respondents, 175 are adopters and 186 are non-adopters. The Chi-square tests indicated that the gender and age of business did influenced the adoption levels amongst MSMEs. Majority of the adopters used social media, followed by e-marketing and digital contents. Information sharing, communication with customers as well as advertising and promotion respectively were found to be the key motives for using digitalmarketing applications. Over sixty (60) per cent of the non-adopters stated their intention to adopt digitalmarketing but only 21.4 per cent of them intended to do so within a year. Enterprise "doesnot know how to best utilize digital marketing in business", "not enough resources (time, monetary, employee and external support)" as well as "not enough skillsand $k$ no wledge to implement digital marketing", reported by 46.2 per cent of the non-adopters. This indicates that mo st Malaysian MSMEs were lack of a wareness especially knowledge and internal resources to apply this type of technology. The se findings have important implications and value for the research community, MSMEs and policymakers in terms of formulating improved strategies for digital marketing adoption and applications. The results also lend answers on why some MSMEs have chosen to adopt digital marketing technologies, while other MSMEs which face similar mark et conditions have not.
\end{abstract}

Keywords--- MSME, digital marketing, entrepreneurs, adopters, non-adopters

\section{INTRODUCTION}

Various studies have shown that by strategically harnessing the power of Internet, bu siness organizations may able to increase profit maximization through strategic online marketing approach which covers broad spectrumof ap plic atio ns that enable businesses to formvirtual relationships with its customers, potential buyers, resellers, suppliers and busin ess partners around the world. Hongyu and Dongmei (2011) suggested that, the advent of the Internet has chang ed g lobal business and marketing landscape especially on how they distributeproduct's information among cu stomers and how they interact with supply and demand as well as buy and sell. Internet usage started mainly as a means of communication via electronic mails (E-mail) and for providing information via online news and homepages on the W eb (Drew, 2003). According to International Telecommunication Union (ITU) (2018), as of June 2017, 54.4 per cent of the world's population has Internet access, with Asia has the most Internet users representing 48.7 per cent from that population.

Des pite the efforts of the Government and various support schemes, only 30 per cent of the local MSMEs have their own websites as revealed by the Malaysian Small and MediumIndustry Association in 2013. Some are still at the in it ial stage, and or not progressing much beyondE-mail and simple information-based webpage s. Ang, Tahar and Murat (2013), mentioned that, although Malaysian MSMEs have company website but most of the functions are limited to ju st for corporate image purposes only and neglected the importance of website for communication and promoting p ro du cts and services. In fact, MSMEs owners or managers still do not know and understand the strategic value of digital marketing on their businesses (Lim, Baharudin \& Low, 2017). The number of MSMEs achieving advanced stag es of digital marketing is very low as compared to larger corporations (Omar et al., 2011). Therefore, in view of the low 
adoption of digital marketing applications among MSMEs and lag of digital marketing research being done in Malaysia within the context of MSMEs, there is a need and worth to investigate the profiles of adopters and non-adopters of digital marketing among Malaysian MSMEs.

\section{PAST STUDIES}

Research on small and medium-sized enterprises (SMEs) has been widely conducted all over the world. Those studies focus on many areas related to SMEoperations including determinants affecting e-commerce adoption and differences between adopters and non-adopters of e-commerce (Abdullah, Wahab \& Shamsuddin, 2013; Yeboah-Boateng \& Essandoh, 2014; Ahmad et al., 2015; Rahayu \& Day, 2015; Ramayah, Ling, Taghizadeh \& Rahman, 2016; Araujo \& Zilber, 2016; Lim, Baharudin \& Low, 2017). In Malaysia however, few researches found to investig ate the ado ption of digital marketing among MSMEs. Thus, further investig ation should be encouraged to enrich the body of knowledge.

\subsection{Malaysian MSMEs}

Since Malaysia is well-positioned and strategically located in the Asia region which has been regarded as the mo st populated Internet users in the world by ITU, the Malaysian MSMEs should take this advantage by adopting dig it al marketing in their businesses to help themgrow and participate in new opportunities b oth locally and g lobally. The benefits associated with digital marketing among MSMEs have received empirical attention in the past such as Mele war and Smith (2003) who found that the Internet may enhance the ability of MSMEs to identify and evaluate in te rnational competitors apart from developing networks of contacts and partners in foreign markets. With the ability to enter international markets at minimal costs, digital marketing may provide wider opportunities for the Malaysian MSMEs to reach new potential customers around the world. According to SMECorporation (2015), Malaysian MSMEs contribute d 36 per cent to the national GDP in 2014, and this is expected to grow at around 10 percent annually to reach 49 per cent by 2020. This is also supported by Malaysia DigitalEconomy Corporation(MDEC) (2017) that s tated, Malaysia has a large segment of the population that is well-versed in technology and mostMalaysians who use the Internet spend more than 16 hours online each week. Consistently, more than 67 per cent of the population currently are considered as Internet users or netizens, and 80 percent of these netizens are es timated to have made online purchase s before, a rate that is comparable to other countries such as Thailand, Singapore, India, and China. Malaysia has about 12 per cent of people using credit card, the second highest in ASEAN, behind Singapore's 37 per cent but well ahead of Thailand's 5 percent and Indonesia's 1 per cent. Malaysia also has solid e-Commerce platforms, including onlinemarketplaces such as Lelong and Mudah, and big international companies such as Zalora and Lazada have entered the market. The Internet businessinfrastructure is also supported by well-developed regulations, including the Electronic Commerce Act (ECA) and the Personal Data Protection Act(PDPA).

\subsection{Digital Marketing and ICT adoption in MSMEs}

The term digital marketing may be perceived as the new and latest ICT innovation to support business marketing processes that is based on the Internet through the use of digital information and online media, with a view to cre ate, dis seminate and tran sfer of business value in order to achieve marketing objectives and to support the transactions of marketing activities processes such as building customer relationships and enhancing service quality delivery.

MSMEs have unique features that can help them to compete with larger corporations especially when comes to adopt new technologies in their business operations. They are often seen as dynamic organizations and thus are exp ected to easily adapt to modern ICT technologies (Abdullah, Wahab \& Shamsuddin, 2013). MSMEs are more flexible, a d apt to changes, and are better placed to develop and accept new ideas as compared to larger corporations (Bala Subrahman ya, Mathirajan \& Krishnaswamy, 2010). Yeboah-Boateng and Ess andoh (2014) also agreed that MSMEs are easily to ad apt ICT because of their size and nature, they are more flexible and simple organization structures compared to larger corporations, which allows them to be more innovative in their response to rapid technological changes in a globalization environment.

There are substantial evidences that MSMEs has engaged with many technological innovations. Bala Subrahmanya et al. (2010) has found that, MSMEs has witnessed theintroduction of a range of digital marketing applications, ra $\mathrm{ng}$ ing from basic technologies to more complex and advanced IT capabilities, such as Web 2.0. Other studies have also examined the adoption of different ICT applications over recent decades. For example, Kuan and Chau (2001) investig ated the adoption of Electronic Data Interchange (EDI) by MSMEs in Hong Kong while in another study by Rahayu and Day (2015) have studied E-commerce adoption in MSMEs in Indonesia. In a similar vein, a recent study by Ramayah, Ling, Taghizadeh and Rahman (2016) have also identified determinants for website usage in tention among Malaysian MSMEs, reflecting an interest in understanding the adoption of Internet technology in this country.

\subsection{Adopters and Non-adopters of e-commerce}

Firms of all sizes are finding it necessary to establish a Web presence to increase their ability to survive in an increas in gly dynamic and competitive business en vironment (Patrick \& Elaine, 2005). The increase of e-commerce us e by businesses is mostly being driven by large companies. In comparis on with larger companies, the adoption of e- 
commerce by SMEs relatively lags behind (Govindaraju et al., 2015; Alam et al., 2011; Chiliya et al., 2011). Larger companies utilize social media more intensively, and the adopter's org anizational disposition inn ovativeness s trongly influences the continuity and intensity of the innovation's use (Araujo \& Zilber, 2016). Sawyer (2011) arg u es that new social media has brought people from different cultures together in the "global village".

A study by Patrick and Elaine (2005) reported that there are differences between adopters and non-adopters of electronic commerce in SME profes sional s ervice firms in New Zealand. Six factors relating to a firm's external/internal environment were found to underpin adoption. These are: response to technological en vironment/opportunities afford ed by technology; negative attitudes or perceived barriers/impediments to electronic commerce; electronic commerce capability; response to new technology/innovation; customer orientation; and sensitivity to competitive/customer environments.

Pearson and Grandon (2005) conducted a survey on managers/owners of SMEs to identify variables that differentiate between adopters and non-adopters of e-commerce. The results indicated that SMEs most recep tive to ad opting ecommerce have the financial and technological resources, seee-commerce as usefulfortheir firms, and feel external press ure to integrate e-commerce into their organization.

Another study by Ajay and Tobeng (2015) found only three independent factors namely (relative advantage, competitive pressure, IT knowledge) were statistically significant to influence the adoption of e-commerce among SMEs. The relative advantage emerged as the mostimportant factor influencing the adoption of e-commerce among SMEs in terms of relative importance. The Chi-square test indicates that the type of business, occupation level, numbers of employees in the company and academic qualification did influence the adoption levels amongst SMEs whils thow long as owner/manager and gender did not influence the adoption level.

In Indonesia, Rahayu and Day (2017) conducted a survey on 292 SMEs in relation to e-commerce. The results recorded that only $21(7.2 \%)$ out the total respondents have not connected to the internet and they do not have an email, while the others $271(92.8 \%)$ have internet access. The former in this study are classified as non-adopters, whilst the latter are clas sified as e-commerce adopters.

SMEs in the UK are adopting e-commerce, through an exploration of their level and sequence of adoption. The research, which was carried out by means of a mailed ques tionnaire, found four distinct clu sters of adoption. These formed a set of sequential stages, through which firms appear to pass during theadoption of e-commerce. The firms in the first cluster are currently developing their first e-commerce services; the second adoption cluster are using e-mail to communicate with customers, suppliers and employees. Those at the third level of adoption have information-based websites operating and are developing on-line ordering facilities. The most advanced adopters have on-line ord ering in operation and are developing online payment capabilities (Daniel, Wilson, \& Myer, 2002)

In the service sector, there were significant differences between adopters and non-adopters of the service in terms of their perceptual, experience and consumer related characteristics. Internet banking adopters perceived internet banking use as less risky, more user-friendly and more useful compared to internet banking non-adopters. Internet banking non-adopters who intend to use the service in the future (i.e. later adopters) perceived internet banking use as less risky and more useful compared to non-adopters who do not intend to use the service (i.e. laggards). Internet banking adopters were also found to have more experience with mobile internet, and have higher income and longer working hours (Ozdemir, Trott \& Hoecht, 2008).

\section{METHODOLOGY}

This study employs survey method to gather datafrom the MSMEs. Pilot test was conducted using 25 re s pond en ts. Using simple random s ampling technique, $400 \mathrm{MSMEs}$ were selected from the sampling frame available in Perak s tate. 31 MSMEs rejected the in vitation to participate during the pre-notified stage. Hence, 369 responses were sent for survey, There were seven (7) non-u sable res ponses with five (5) from postage and two (2) from e-mail respectively while one (1) response received via postage after the deadline which is considered as no response. 361 responses were valid for analys is, representing 98.1 per cent of completed rate res pectively. The survey was conducted in October 2018 in Perak state, Malaysia and questionnaires were e-mailed or posted to the res pondents according to owner-managers' preferences.

\section{FINDINGS}

\subsection{Owner-managers' Profiles}

In respect of gender characteris tics of the owner-managers of the MSMEs thatparticipated in this survey, majority of the respondents were male repres enting 80.1 per cent or 289 respondents. The survey dat a als o shows a comparable number from a recent study by Ahmad, Suseno, Seet, Susomrith and Rashid (2018) that revealed only 20.6 per cent of Malaysian MSMEs are owned or managed by females. This might be due to the characteristics of the Malaysian's cultural setting and traditions as sociated with the concept of women at work. 
In terms of age group, the result shows that respondents aged 35 to 44 years old compris ed nearly half of the total respondents (44.6\%) while owner-managers between the aged of 25 and 34 years was the second largest group follo wed by 45 to 54 years with 23.5 per cent and 22.2 per cent respectively. However, 7.5 per cent of the population is represented by the older generation aged above 55 years old compared to just 2.2 per cent of the younger generation aged below than 25 years old. These results are not surprising as recents tatistics released by the SMECorporation Malay sia have indicated that the 35 to 44 age group is the dominant decision makers in the country, suggesting a relatively matureentrepreneurs population in this country (SMECorporation, 2015).

On the question of educational attainment, it is worthy to note that, there is still a s mall portion of Malaysians for n ot having any formal educational qualification (4.4\%) and secondary school leavers $(6.9 \%)$, indicating a low ed u cational background of decision makers in the region. Gratefully, the data also shows that educational leveloff those sampled is generally high. More than half(54.8\%) of the respondents' highest qualification was at degree level and $13.9 \mathrm{per}$ cent having Master or PhD while owner-managers with pre-university of diploma represents the second highest group accounting 19.9 per cent of the population, indicating a well-educated decision makers population in the Perak state.

Table 1: Malay sian MSMEs owner-managers' demographic characteristics

\begin{tabular}{lcc}
\hline \multicolumn{1}{c}{ Demographics } & Frequency & Percentage \\
\hline Gender & & \\
Male & 289 & 80.1 \\
Female & 72 & 19.9 \\
& & \\
\hline Age & & \\
Less than 25 & 8 & 2.2 \\
25 to 34 & 85 & 23.5 \\
35 to 44 & 161 & 44.6 \\
45 to 54 & 80 & 22.2 \\
55 to 64 & 26 & 7.2 \\
65 and over & 1 & 0.3 \\
& & \\
\hline Highest education level & & \\
No formal qualification & 16 & 4.4 \\
Primary school & 0 & 0.0 \\
Secondary school & 25 & 19.9 \\
Pre-university or diploma & 72 & 54.8 \\
Degree & 198 & 13.9 \\
Postgraduate - Master/PhD & 50 & \\
& & \\
\hline
\end{tabular}

\subsection{Business Profiles}

Among the participant enterprises, less than a year enterpris eaccounted for only a small prop portion $(6.7 \%)$ of the total sampled enterprises, while those which had been in business for one to three years and four to six years made up 16.6 per cent and 20.2 per cent of the s ample, res pectively. The vast majority were businesses that had been in bu sin es $s$ for more than sixyears (56.5\%), indicating that MSMEs in the region is well-established. Table 2 below pres ents the relevant summary data.

Given the definition of Malaysian MSMEs based on number of employees, the highest proportion (54\%) of the sampled enterprises fell into the s mall-enterpris es categ ory with number of employees between 5 to 74 staffs, while the other two categories, micro-enterprises (less than 5 employees) represents 36 per cent and medium-enterprises ( 75 to 200 employees) accounts for 10 per cent of the sample. This indicates that the sampled MSMEs in the region are led by small-size companies compared to the previous study by Aman et al. (2011) who revealed that micro enterprises are the majority for Malays ian MSMEs if based on number of full-time employees.

As referred to the other definition of Malaysian MSMEs based on approximate annual sales, the highest proportion $(67.3 \%)$ of the sampled enterprises fell into the s mall-enterprises category with approximate annual income of be twe en RM300,000 and less than RM15 millions, while the other two categ ories, micro-enterprises (les s than RM300,000) and medium enterpris es (between RM15 millions and les s than RM50 millions) accounts for 22.7 percent and 10.0 per cent of the sample, respectively. Similarly, this results als o indicates that the sampled MSMEs in the region are led by s mallsize companies if based on approximate annuals ales income. 
As far as the make-up of the sample by industry sector is concerned, the survey results in dicate that the sample comprised MSMEs from manufacturing (24.6\%), services (57.1\%) and others (18.3\%), demonstrating a similar proportional record by SMECorporation (2015).

Table 2: Malaysian MSMEs demographic characteristics

\begin{tabular}{|c|c|c|}
\hline Demographics & Frequency & Percentage \\
\hline $\begin{array}{l}\text { Age ofbusiness organization } \\
\text { Les s than a year } \\
1 \text { to } 3 \text { years } \\
4 \text { to } 6 \text { years } \\
\text { More than } 6 \text { years }\end{array}$ & $\begin{array}{c}24 \\
60 \\
73 \\
204\end{array}$ & $\begin{array}{c}6.7 \\
16.6 \\
20.2 \\
56.5\end{array}$ \\
\hline $\begin{array}{l}\text { Total number ofemployees } \\
\text { Les s than } 5 \\
5 \text { to } 29 \\
30 \text { to } 74 \\
75 \text { to } 200\end{array}$ & $\begin{array}{l}130 \\
171 \\
24 \\
36\end{array}$ & $\begin{array}{c}36.0 \\
47.4 \\
6.6 \\
10.0\end{array}$ \\
\hline $\begin{array}{l}\text { Approximate annual sales } \\
\text { Les s than RM } 300,000 \\
\text { RM } 300,000 \text { and les s than RM3 million } \\
\text { RM } 3 \text { million and les s than } 15 \text { million } \\
\text { RM } 15 \text { million and less than RM } 20 \text { million } \\
\text { RM } 20 \text { million and less than RM } 50 \text { million }\end{array}$ & $\begin{array}{c}82 \\
177 \\
66 \\
20 \\
16\end{array}$ & $\begin{array}{l}22.7 \\
49.0 \\
18.3 \\
5.5 \\
4.5\end{array}$ \\
\hline $\begin{array}{l}\text { Main business sector } \\
\text { Manufacturing } \\
\text { Services } \\
\text { Others }\end{array}$ & $\begin{array}{c}89 \\
206 \\
66\end{array}$ & $\begin{array}{l}24.6 \\
57.1 \\
18.3\end{array}$ \\
\hline $\begin{array}{l}\text { Marketarea } \\
\text { Urban market } \\
\text { Rural market } \\
\text { National market } \\
\text { International market }\end{array}$ & $\begin{array}{c}108 \\
20 \\
156 \\
77\end{array}$ & $\begin{array}{c}29.9 \\
5.5 \\
43.3 \\
21.3\end{array}$ \\
\hline
\end{tabular}

Which regards to market area, the survey data reveals that 78.7 per cent of the surveyed MSMEs focused their business activities inside the country, with 29.9 per cent having an urban scope, 5.5 percent at rural areas and the balance 43.3 percent are reachable nation wide. It can be also observed that the percentag e of en terpris es catere d on $\mathrm{g}$ lobal markets accounted only 21.3 per cent, suggesting that Malaysian MSMEs are more likely to cater on domestic and national markets than to expand activities in globally. This may imply that MSMEs in Malaysia are highly dependent on local and national markets.

\subsection{Application of Digital Marketing}

From the 361 responses, 175 were adopters, representing 48.5 percent of the sample and 186 were non -adopters cases, representing 51.5 per cent respectively. The level of digital marketing adoption among Malaysian MSMEs is moderately low. This may suggest that the rate of digital marketing adoption and applications among Malaysian MSMEs are still far behind as compared to the current 67 percent of Internet users in Malaysia as reported by MDEC (2017).

Table 3: Adopters and Non-adopters of MSMEs ( $\mathrm{n}=361$ )

\begin{tabular}{lcc}
\hline \multicolumn{1}{c}{ Status } & Frequency & Percentage \\
\hline Adopter & 175 & 48.5 \\
Non-Adopter & 186 & 51.5 \\
\hline
\end{tabular}




\subsection{Digital Marketing Tools Use by Adopters}

Table 4 shows the common tools and components of digital marketing application by the MSMEs adopters. Majority of the adopters used social media $(167 / 175=95.4 \%)$ in running the business. One hundred and ten $(110)$ enterpris es or 62.9 percent were found to useE-mail marketing, while digital content tools such as YouTube, blogs or website were the third most widely-applied platform used by MSMEs in Malaysia, with slightly more than half (52\%). E-commerce platforms such as Lazada, Alibaba or Mudah.my ranked theleast applied digital marketing tool in the country (25.1\%) indicating that most Malaysian MSMEs were still running their business via the conventional brick and mortar concept.

Table 4: Digital marketing tool and components used by adopters $(n=175)$

\begin{tabular}{lcc}
\hline \multicolumn{1}{c}{ Tools } & $\begin{array}{c}\text { No. of } \\
\text { adopters }\end{array}$ & Percentage \\
\hline Social Media & 167 & 95.4 \\
E-mail Marketing & 110 & 62.9 \\
Digital Contents & 91 & 52.0 \\
E-commerce & 44 & 25.1 \\
\hline
\end{tabular}

\subsection{The Purpose of Using Digital Marketing Tools and Components}

A multiple-response question was asked to the adopting enterprises aimed to elicit information on the purpose of using digitalmarketing tools and components. The result shows that, information sharing $(88.6 \%)$, communication with customers $(85.7 \%)$ as well as advertising and promotion $(81.7 \%)$ res pectively were found to be the key motives for using digital marketing applications. This may give indication on why so cial media platforms dominating Malaysian MSMEs as it may provide them with these purposes. This may also suggest that most Malaysian MSMEs consider digital marketing as a tool to create awareness among consumers about their products and services by sharing useful information. It is interesting to note that more than half adopters used digital marketing to gain benefits from bran ding $(61.1 \%)$, getting referrals $(61.1 \%)$, receive customers feedback $(61.1 \%)$, develop customer relations $(60.6 \%)$ as well as to reach new cus tomers (58.3\%). A smaller percentage of adopters use digital marketing tools and components to en han ce both their customer service activities and conducting market research with only 34.9 per cent and 29.7 per cent res pectively. This might also reveal lack of knowledge among MSMEs' owner-managers on data manipulation skill sets for effective marketing plan and strategy for their businesses - Refer to Table 5.

Table 5: Purposes of digital marketing application among adopters MSMEs $(\mathrm{n}=175)$

\begin{tabular}{lcc}
\hline \multicolumn{1}{c}{ Purpose } & No. of adopters & Percentage \\
\hline Information sharing & 155 & 88.6 \\
Communication with customers & 150 & 85.7 \\
Advertising and promotion & 143 & 81.7 \\
Branding & 107 & 61.1 \\
Getting referrals & 107 & 61.1 \\
Receive customers feedback & 107 & 61.1 \\
Develop customer relations & 106 & 60.6 \\
To reach new customers & 102 & 58.3 \\
Customers service activities & 61 & 34.9 \\
Conducting market research & 52 & 29.7 \\
\hline
\end{tabular}

\subsection{Non-adopters intention to adopt digital marketing}

The non-adopters as the second group of respondents were asked question related to their adoption intention plan. As has been previously mentioned, 51.5 per cent or 186 of the surveyed MSMEs did not have a digital presence. The se MSMEs were asked to state their intention plan with regards to adoption, making clear whether they intended to adopt or not. Just over 60 per cent of the nonadopters stated their intention to adopt digital marketing as shown in Table 6 below, indicating a moderate of digital marketing adoption rate in the region.

\subsection{Timeline to adopt digital marketing among MSMEs non-adopters}

All the 112 intended non-adopters were then asked their intention timeline to adopt dig it al marketing in the near future and surprisingly, only 21.4 per cent of themintended to do so within a year as stated in Table 7 . demon s trat ing a 
very slow time rate required for Malaysian MSMEs to adopt digitalmarketing applications in the near future. Howe ver, majority of them $(35.7 \%)$ were intended to adopt in between 13 to 18 months period and about 28.6 per cent of non adopters will take longer than 24 months to apply digital marketing while 14.3 per cent of them have no plans at all. Thus, it can be summarized that the number of late adopters $(85.6 \%)$ were more than those lag gard group (14.3\%), which means MSMEs in this state are in the process of adopting digital marketing application. Thus, continuous encouragement should be given to them to speed up the adoption process.

Table 6: Intention to adopt digital marketing applications among non-adopters $(n=186)$

\begin{tabular}{lcc}
\hline \multicolumn{1}{c}{ Non-adopters } & Frequency & Percentage \\
\hline Has Intention & 112 & 60.2 \\
No Intention & 74 & 39.8 \\
\hline
\end{tabular}

Table 7: Timeline for non-adopters to adopt digital marketing $(\mathrm{n}=186)$

\begin{tabular}{lcc}
\hline \multicolumn{1}{c}{ Duration } & Frequency & Percentage \\
\hline Less than 6 months & 27 & 14.3 \\
6-12 months & 13 & 7.1 \\
13-18 months & 66 & 35.7 \\
More than 24 months & 53 & 28.6 \\
No plan & 27 & 14.3 \\
\hline
\end{tabular}

\subsection{Barriers to adopt digital marketing among non-adopters MSMEs}

Many barriers to adopt digital marketing were listed in the survey questionnaire. Enterprise "does not know how to best utilize digital marketing in business", "not enough res ources (time, monetary, employee and external s upport)" as well as "not enough skills and knowledge to implement digital marketing", reported by 46.2 per cent of the non -adopters, indicating that most Malaysian MSMEs were lack of awarenes s especially knowledge and internal resources to apply this type of technology. "Our customers do not require us to apply digital marketing" and "the enterprise just not interested to ad opt digital marketing" were two other major barriers that were identified with 42.3 per cent and 33.3 percent of cas es res pectively. No benefit gaining fromusing digital marketing was also mentioned by respondents as a barrier to a p ply digital marketing in their enterprises as well as the enterprise can do well without digital marketing, but with less reported cases of 20.5 per cent and 16.7 per cent res pectively as recorded in Table 8 . The lowes t res ponse barriers to hinder the adoption of digital marketing application was thenon-adoption by their competitors with ju st 5.13 per cen $\mathrm{t}$ only.

Table 8: Barriers that hindered the adoption of digital marketing applications $(n=186)$

\begin{tabular}{lcc}
\hline & Frequency & Percentage \\
\hline Does not know to utilize digital marketing & 86 & 46.2 \\
Not enough resources & 86 & 46.2 \\
Not enough skills and knowled ge to implement digital & 86 & 46.2 \\
marketing & 78 & 42.3 \\
Our customers do not require us to apply digital marketing & 62 & 33.3 \\
The enterprise justnot interested to adopt digital & & \\
marketing & 38 & 20.5 \\
No benefit gaining fromusing digitalmarketing & 31 & 16.7 \\
The enterprise can do well without digital marketing & 10 & 5.13 \\
Competitors do not use digital marketing & & \\
\hline
\end{tabular}

\subsection{Crosstabulation and Chi-Square Tests}

The Chi-square test indicates that the gender and age of business did influence the adoption levels amongst MSMEs whilst academic qualification, owner/manager age, business sector and annual sales did not influence the adoption level.

Table 9 shows a significant relationship between gender and digital marketing adoption. Male were found to be adopters and female be non-adopters. The Pearson Chi-Square value was 50.27 and signific ant $(\mathrm{p}=0.00)$. This re sult contradicted with a study on adoption of e-commerce among SMEs by Ajay and Tobeng (2015). 
Table 9: Digital marketing application and Gender $(n=361)$

\begin{tabular}{llccc}
\hline & & \multicolumn{3}{c}{ Gender } \\
& & Male & Female & Total \\
\hline Digital marketing & Non-adopters & 122 & 64 & 186 \\
application & Adopters & 167 & 8 & 175 \\
& Total & 289 & 72 & 361 \\
\hline
\end{tabular}

When digital marketing application was crosstab with organization age, it was found that adopters and non-a dopt ers were significantly different. Surprisingly, adopters are those who are in business between 0-3 years while non-adopt ers are those in business for 4 and more years. The Pears on Chi-Square value was 7.903 and sig nificant $(p=0.005)$. This finding explained that the new businesses are more willing to adopt digital marketing in their operation as compared to those older businesses. This result contradicted with a study on adoption of e-commerce among SMEs by Ajay and Tobeng (2015) - Refer to Table 10.

Table 10: Digital marketing application and Organization age $(n=361)$

\begin{tabular}{lcccc}
\hline & & \multicolumn{3}{c}{ Organization Age } \\
& & & 4 years and \\
& & $\mathbf{0 - 3}$ years & more & Total \\
\hline Digital marketing & Non-adopters & 32 & 154 & 186 \\
application & Adopters & 52 & 123 & 175 \\
& Total & 84 & 277 & 361 \\
\hline
\end{tabular}

Table 11 however revealed the insignificant linear relationship between annual sales and digitalmarketing adop tio $n$. The numbers of adopters and non-adopters are dis similar no matter whether the annuals ales are les s or mo re than 3 million. Majority of the adopters and non-adopters (more than 70\%) earned annual sales les s than three million. The Pears on Chi-Square value was 0.17 and insignificant $(\mathrm{p}=0.890)$.

Table 11: Digitalmarketing application and Annual sales $(n=361)$

\begin{tabular}{llccc}
\hline & & \multicolumn{2}{c}{ Annual Sales } & \multicolumn{2}{c}{ Total } \\
& & Less than 3 million & 3 million and more & \\
\hline Digital marketing & Non-adopters & 134 & 52 & 186 \\
application & Adopters & 125 & 50 & 175 \\
& \multicolumn{1}{c}{ Total } & 259 & 102 & 361 \\
\hline
\end{tabular}

\section{DISCUSSION}

As mentioned earlier, the non-adopters (186) digital marketing application were more than the adopters (175) grou p. However, more than 80 per cent of the non-adopters were late adopters and about 14 per cent were laggards. Thus, the res earchers have high confident that MSMEs in Malaysia will adopt digital marketing in their bus iness even though a longer time (e.g. 3 years) is required for themto make an adoption. Related to these findings, the researchers agreed th at there will be a gap between the adopters and non-adopters business performance. Those adopters will gain more benefits from the digitalmarketing they practiced as compared to those non-adopters segment who are slow in adopting the technology.

Even though adopters are using all digital marketing tools listed in the questionnaire, but most of them are using social media and e-marketing contents. Digital contents ande-commerce are less popular among them. Ado pters als o revealed that they are using digital marketing application for many purposes, however majority of them us ed dig ital marketing for information sharing, communication with customers and advertising via promotion.

For the non-adopters, more than 50 percent of them will adopt digital marketing before two years. About 30 per cent will adopt after 2 years. Thus, within two years in the future, it is expected that the number of adopters of digital marketing will be more than the non-adopters. As such, aggressive encouragement should be given to n on-adop te rs to 
speed up the adoption process if the record of MSMEs adopters of digital marketing application in Perak state need to be increased.

When cross-tabulation analyses were performed, only two demographic variables found to have significant relationship with digital marketing adoption. Male entrepreneurs were group as adopters while female counterparts were group as non-adopters. To answer for this dissimilarity, the data revealed that many female entrepreneurs are operat ing the business for four years and more but the business size in average are small. Thus, the motivation for them to ad opt digital marketing is slow. In addition to that, those who are new in the business be adopters in digital marketing. The best answer to support the finding is even though they are new in business, but they have knowledge about digital marketing and realized about the benefits offered by new technology to their business. Thus, they are eager to spent time and energy to implement digital marketing in day-to-day operation.

\section{CONCLUSION}

In Malaysia, MSMEs can be grouped into adopters and non-adopters. Adopters are th ose who are eager to apply digital marketing in their day-to-day operation while non-adopters are those who are less ready to adopt digital marketing, but some enterprises do have intentions to adopt the technology in the future. As to encourage the MSMEs to adopt digital marketing, more training and financial as sistance should be given to themto speed up the acceptance of technology development in theirbusinesses. Actions fromdepartments concern should be taken imme diately because about 46 per cent of the non-adopters stated that they do not adopt digital marketing due to threemain barriers: 1) Do es not know to utilize digital marketing; 2) Not enough resources; 3) Not en ough skills and knowled ge to implement digital marketing. MSMEs must be exposed on the strategic value of digital marketing in helping them to capture a bigger market both in local and global level. Due to that, future research should embark on the benefits of using digital marketing in capturing bigger customers, sales, market size and market share.

\section{REFERENCES}

Abdullah, N. H., Wahab, E. \& Shamsuddin, A. (2013). Exploring the common technology adoption enablers amo $\mathrm{g}$ Malaysian SMEs: Qualitative findings. Journal of Management \& Sustainability, 3(4), $78-91$.

Ahmad, N.H., Suseno, Y., Seet, P.S., Susomrith, P., \& Rashid, Z. (2018). Entrepreneurial Competencies and Firm Performance in Emerging Economies: A Study of Women Entrepreneurs in Malaysia. In Knowledge, Learnin g and Innovation. (pp. 5-26). Springer, Cham.

Ahmad, S. Z., Abu Bakar, A. R., Faziharudean, T. M \& Mohamad Zaki, K. A. (2015). An Empirical Study of Factors Affecting e-Commerce Adoption among Small- and Medium-Sized Enterprises in a Develo pin $g$ Coun try: Evidence from Malaysia, Information Technologyfor Development, 21(4), 555-572.

Ajay, K. G. \& Thobeng C. (2015). The adoption of electronic commerce by small and medium enterprises in Pretoria. The Electronic Journal of Information Systems in Developing Countries, 68(7), 1-23.

Alam, S. S., Ali, M. Y., \& Jani, M. F. M. (2011). An empirical study of factors affecting electronic commerce adoption among SMEs in Malaysia. Journal ofBusiness Economics and Management, 12(2), 375-399.

Aman, O., Tahir, M. N. H., Majid, I. A., Aziz, N. A. A. \& Rahmiati, F. (2011). The success factors of food small medium entrepreneurs under the one dis trict one industry programme: A case on food manufacturing entreprene urs in Melaka. Journal of GlobalEntrepreneurship, 1(1), 44-64.

Ang, C. L., Tahar, R. M., \& Murat, R. (2003). An empirical study on electronic commerce diffusion in the Malays ian shipping industry. The Electronic Journal of Information Systems in Developing Countries, 14(1), 1-9.

Araújo, J. B. \& Zilber, S. N. (2016). What Factors Lead Companies to Adopt Social Media in their processes: Proposal and Test of a Measurement Model, Brazilian Business Review, 13(6), 260-290. http://dx.doi.org/10.15728/bbr.2016.13.6.5

Bala Subrahmanya, M. H. \& Mathirajan, M. \& Krishnaswamy, K. N. (2010). Importance of Technological Innovation for SME Growth - Evidence from India, MERIT Working Papers 007, United Nations University Maas tricht Economic and Social Res earch Institute on Innov ation and Technology (MERIT).

Chiliya, N., Chikandiwa, C., \& Afolabi, B. (2011). Factors Affecting Small Micro Medium Enterpris es'(SMMEs ) Adoption of E-Commerce in the Eastern Cape Province of South Africa. International Journalof Business and Management, 6(10), 28-36.

Daniel, E. Wilson, H, \& Myer, A. (2002). Adoption of E-Commerce by SMEs in the UK: Towards a Stage Mo del. International Small Business Journal: Researching Enterpreneuship, 20(3), 253-270. https://doi.org/10.1177/0266242602203002 
Drew, S. (2003). Strategic uses of E-Commerce by SMEs in the east of England. European Management Journal, 21(1), 79-88.

Govindaraiu, R., Wiratmadia,I. I., \& Rivana, R. (2015). Analysis of drivers fore-commerce adoption by SMEs in Indonesia. Paper presented at the Interdisciplinary Behavior and Social Sciences:Proceedings of the International Congress on Interdisciplinary Behaviour and Social Sciences 2014.

Hongyu, W. \& Dongmei, Z. (2011). Internet technology's development and its positive role in promoting EMarketing. Energy Procedia, 5, 6504-6507.

International Telecommunication Union (2018). Retrieved June 12, 2018, from http://www.w3.org/Graphics/JPEG/itu-t81.pdf

Kuan, K. K. \& Chau, P. Y. (2001). A perception-based model for EDI adoption in small businesses using a technology-organization-environment framework. Information \& Management, 38(8), 507-521.

Lim, S. C., Baharudin, A. S. \& Low, R. Q. (2017). Factors Influence SMEs in Malaysia to Adopt E-commerce: Moderating Roles of Perceived Strategic Value. Journal of Engineering and Applied Sciences, 12(6), 1566-1574.

Malaysia DigitalEconomy Corporation(MDEC) (2017). Retrieved June 12, 2018, from https://www.mdec.my/

Melewar, T, \& Smith, N. (2002). The Internet Revolution: Some Global Marketing Implications, Marketing Intelligence \& Planning, 21 (6), 363-369. https:doi.org/10.1108/02634500310499220

Omar, A., Ramayah, T., Lin, L. B., Mohamad, O., \& Marimuthu, M. (2011). Determining factors of the usage of web-based marketing applications by small and medium enterprises (SMEs) in Malaysia. Journal of Marketing Development and Competitiveness, 5(2), 70-86. http://www.nabusinesspress.com/jmdcopen.html

Ozdemir, S., Trott, P. \& Hoecht, A. (2008). Segmenting internet banking adopter and non-adopters in the Turkish retail banking sector. International Journal of Bank Marketing, 26(4), 212236. https://doi.org/10.1108/02652320810884777

Patrick. M. \& Elaine, R. (2005). A Profile of Adopters and Non-adopters of eCommerce in SME Professional Service Firms. Australasian Marketing Journal, 13(1), 36-48.

Pearson, J. M. \& Grandon, E. E. (2005). An Empirical Study of Factors that Influence E-Commerce Adoption / Non-Adoption in Small and MediumSized Businesses, Journal of Internet Commerce, 4(4), 1-21.

Rahayu, R. \& Day, J. (2015). Determinant factors of e-commerce adoption by SMEs in developing country: evidence from Indonesia. Procedia-Social and Behavioural Sciences, 195, 142-150.

Rahayu, R. \& J. Day (2017). E-commerce adoption by SMEs in developing countries: Evidence from Indonesia. Eurasian Business Review, 7(1), 25-41.

Ramayah, T., Ling, N. S., Taghizadeh, S. K. \& Rahman, S. A. (2016). Factors influencing SMEs website continuance intention in Malaysia. Telematics and Informatics, 33(1), 150-164.

Sawyers, R. (2011). The impact of new social media on intercultural adaptation:Honors Programat the Univ ersity of Rhode Is land.

SME Corporation (2015). Definitions of SME by group. Retrieved July 3, 2018, from http://www.smecorp.gov.my/index.php/en/policies/2015-12-21-09-09-49/smedefinition

Yeboah-Boateng, E. O. \& Essandoh, K. A. (2014). Factors influencing the adoption of cloud co mputing by s mall and mediumenterprises in developing economies. International Journal of Emerging Science and Engineering, 2(4), 13-20. 